\title{
Development Trends in Motivation Factors Applied by Business Managers in Corporation
}

\begin{abstract}
The aim of the paper is to determine the development trends in motivation factors. In the first part, the authors analyse apparent differences in the use of motivation factors by business managers. Then, the authors try to determine the role and influence of independent variables, namely leadership style, corporate culture and corporate communication on employee motivation.
\end{abstract}

Keywords: corporate culture, communication, leadership, motivation factors, manager.

Straipsnio tikslas - apibrèžti motyvacinius veiksnius bei jų vystymo galimybes. Pirmoje dalyje analizuojami verslo vadovų naudojami motyvacijos būdų skirtumai. Po to buvo stengtasi nustatyti vaidmenų ir nepriklausomų kintamųjų, tokių kaip, lyderystès stilius, organizacinè kultūra ir organizacijos komunikacija įtaką darbuotojų motyvacijai.

Raktiniai žodžiai: organizacinè kultūra, komunikacija, lyderysté, motyvaciniai veiksniai, vadovas.

\section{Introduction}

"If you want to achieve lasting success, the motivation that drives you to this goal must come from the inside. It does not matter who you are, how old you are ... " P. J. Meyer (2018).

In this paper we determine the development trends in motivation factors applied by 285 business managers in organizations among which is the world's largest food and beverage international corporation.

Knowing how to properly motivate employees is one of the basic prerequisites for successful business operation. The company's real interest in the employee's life inspires the other side to try to be interested in the company.

The Business Leaders Forum recommendations for companies on employees' motivation are as follows:

1. Consider the importance of people first.

2. Focus on processes.

3. Offer career advancement to employees.

4. Reward the employee with a salary corresponding to his/her contribution to the company.

Zuzana LUŠŇÁKOVÁ - Ing., PhD, Faculty of Economic and Management, Department of Management, Slovak University of Agriculture. Address: Tr. A. Hlinku 2, Nitra, Slovakia. E-mail: ,zuzana.lusnakova@uniag.sk.

Mária ŠAJBIDOROVÁ - Doc. Ing., PhD, Faculty of Economic and Management, Department of Management, Slovak University of Agriculture. Address: Tr. A. Hlinku 2, Nitra, Slovakia. E-mail: maria.sajbidorova@uniag.sk.

Zuzana JURÍČKOVÁ - Ing. Bc., PhD, Faculty of Economic and Management, Department of Management, Slovak University of Agriculture. Address: Tr. A. Hlinku 2, Nitra, Slovakia. E-mail: zuzana.jurickova@uniag.sk. 
5. Explain the employee's recognition so that he/she may feel important to and part of the company.

An employee can do assigned tasks and perform a job for two reasons. First, accomplishment of the task will involve financial or other reward. In that case, we are talking about stimuli. The second possibility is when an employee is internally convinced of the importance of this task. The employee works well, regardless of whether or not he/she is rewarded. In this case we are talking about the motives. The disadvantage of stimulation is when an employee loses the offer of positive values, then he/she loses motivation and stops working. However, the incentive advantage lies in the fact that if the employee has sufficiency of motives, he continues to work with the belief that he is doing the right thing (Plamínek, 2015). When employees are highly motivated, they will put more effort on the job and enhance their productivity and the quality of their performance. Managers need to motivate employees continuously and provide on-going feedback for employees. Since feeling good about themselves, having a sense of accomplishment, taking responsibility, and having challenging work are good motivators for employees, managers should compliment their employees and recognize employees who well do their job. Managers should listen to employees, care about employees, encourage employees to be involved in job or job-related decisions, take care of employee advancement or career growth, and reward employees with pay increases or bonuses (Chiang, Jang, 2008).

The motivation process is much more complicated than it may seem because every employee in the company has the needs and goals and also a different way of satisfying and achieving them. This means that one approach to motivation stimulation will not suit all employees and therefore there is motivation in the form of remuneration. Effective motivation stimulation will only work if it is well set, understood and applied.

For meaningful and effective raising of the level of motivation, it is appropriate for the company to create a sufficiently rich structure of individualized and group motivation programs that are covered by the motivation program of the company. In this way the aim can be achieved, that motivational influences and efforts in the enterprise are coordinated and tuned.

Thus, the article focuses on analysing development trends in motivation factors in a corporation. The research problem is formulated as follows:

- Do business managers differentiate the strength of motives of their subordinates?

- What is the role of leadership style, corporate culture and corporate communication in the employees' motivation process?

The object of research is the process of employees' motivation in a chosen international corporation.

The aim of research is divided into two parts. In the first one, we analyse the difference in the use of motivation factors by business managers. In the second part of the paper, we determine the role and influence of leadership style, corporate culture and corporate communication on employee motivation in a chosen international corporation. 
Research methods. Data processing was performed using MS EXCEL 2016 and SPSS. Mathematical and statistical methods and tests such as Friedman's Test, Wilcoxon Test were applied for statistical hypothesis testing. Structural equation modelling was used to determine the correlation between dependent and independent variables.

\section{Theoretical background}

Motivation is a set of motives (internal incentives) in the consciousness of man that give the power to decide about the alternatives of the proceedings, the causes of the action and the orientation. Motivational process takes place in a mental spirit of the person and is a driving force for achieving the objective - the performance of tasks. According to the power of motivation to work, one distributes his energy individually and takes different attitudes towards certain activities and tasks. According to his attitudes, he works either willingly or reluctantly, reflecting his success, respectively failure at work (Čihovská et al., 2007; Šajbidorová, 2008). Commitment is critical to organizational performance, but it is not a panacea. In achieving important organizational ends, there are other ingredients that need to be added to the mix. When blended in the right complements, motivation is the result". Employee motivation is influenced by a complex system of managerial and organizational factors. If we take as a given that a motivated workforce can boost company performance, then the insights into human behavior will help companies and executives get the best out of employees by fulfilling their most fundamental needs (Nohria, Groysberg, Lee, 2008).

As shown in Figure 1, the most prominent theories of work motivation address the proximal, intra-individual psychological forces, mechanisms, and processes that determine goal choice and action (i.e., the why, how, and what of motivation).

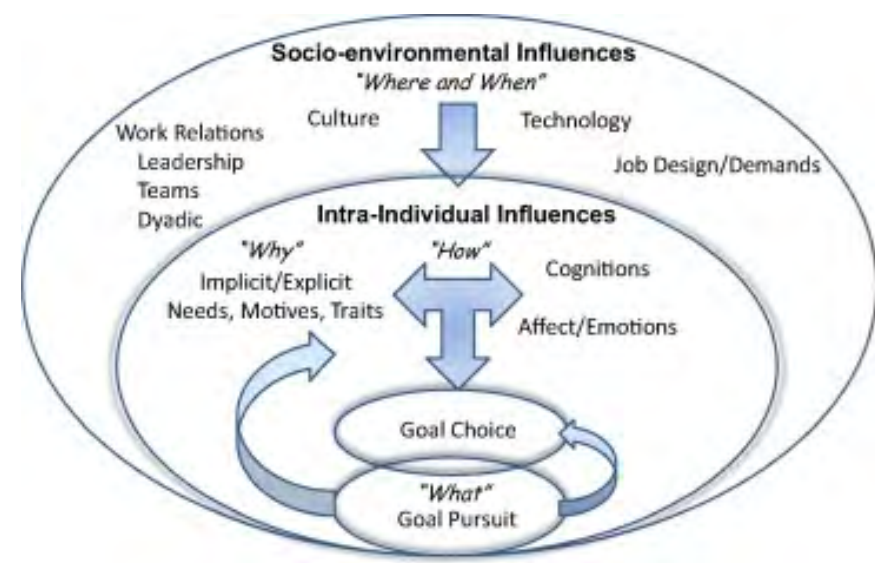

Fig. 1. The most prominent theories of work motivation

Source: R. Kanfer, G. Chen (2016). 
Within-person formulations in this segment of the picture, derive from three distinct but related streams of research. "Why" accounts of motivation and may be traced back to the early 20th century work on the identification of universal human motives and tendencies (Kanfer, Chen, 2016).

The efficiency of human resources motivation system has a significant impact on the effectiveness. For the purposeful work results of the administration offices of human resources, it is important to analyse not only the existing functions and procedures, but also to investigate the factors that affect the motivation of human resources in performing the functions and procedures effectively (Raudeliūniené, Meidutè, Kavaliauskiené, 2014).

S. Ramlall (2004) compiled the major factors from the respective motivation theories and explained how they could affect employee retention efforts. The motivation factors are as follows.

- Needs of the Employee - Employees have multiple needs based on their individual, family, and cultural values.

- Work Environment - Employees want to work in an environment that is productive, respectful, provides a feeling of inclusiveness, and offers friendly setting.

- Responsibilities - Given that one feels competent to perform in a more challenging capacity and has previously demonstrated such competencies, an employee may feel a need to seek additional responsibilities and be rewarded in a fair and equitable manner.

- Supervision - Managers and other leaders more frequently than others feel a need to teach, coach, and develop others. In addition, these individuals would seek to influence the organization's goals, objectives and the strategies designed to achieve the mission of the organization.

- Fairness and Equity - Employees want to be treated and rewarded in a fair and equitable manner regardless of age, gender, ethnicity, disability, sexual orientation, geographic location, or other similarly defined categories.

- Effort - Even though employees may exert higher levels of effort into a position based on a perceived significant reward, this could be a short-term success if the task itself does not challenge or provides satisfaction to the employee.

- Employees' Development - Employees prefer to function in environments that provide a challenge, offers new learning opportunities, significantly contributes to the organization's success, offers opportunities for advancement and personal development based on success and demonstrated interest in a particular area.

- Feedback - Individuals prefer to have timely and open feedback from their supervisors. This feedback should be an ongoing process during the year and not limited to formal performance reviews once or twice per year. In addition, the feedback should be from both the employee and the supervisor.

The results of the study made by M. B. Dermody, M. Young and S. L. Talyor (2004) indicate that motivation is influenced by both financial and non-financial incentives. Although compensation and monetary awards appear to be the most important factors (over $50 \%$ of the sample) for employees in choosing to work in and remain in the industry, other important motivation factors were also discovered such as relationships with co-workers, flexible working hours, atmosphere of restaurant. 
The most effective way to motivate the employees - to engender a strong sense of camaraderie - is to create a culture that promotes teamwork, collaboration, openness, and friendship. Culture-building efforts, such as Employee Appreciation Week, are clearly aimed at creating a sense of bonding. The company meets the drive to comprehend by investing significantly in training and development. Employees' perceptions of their immediate managers matter just as much. People recognize that a multitude of organizational factors, some outside their supervisor's control, influence their motivation, but they are discriminating when it comes to evaluating that supervisor's ability to keep them motivated. The drive to comprehend is best addressed by designing jobs that are meaningful, interesting, and challenging (Nohria et al., 2008).

To manage the existing performance of the employees and to motivate them for better performance, efficient communication practices have become more important in all organizations. Internal communication also provides employees with important information about their jobs, organization, environment and each other. Communication can help motivate, build trust, create shared identity and spur engagement; it provides a way for individuals to express emotions, share hopes and ambitions and celebrate and remember accomplishments. (Rajhans, 2012; Gilley et al., 2009)

The result of the study of M. Vetráková and L. Mazúchová (2015) is the finding that the most used tool of managing work motivation are motivation programs that prefer mainly companies.

Motivational programs (both individual and group) can really be an effective tool to improve the company's entire business in all areas of its professional activities. It is true that if the motivation of all employees in the enterprise is strengthened - this means that there is a higher motivation for marketing experts, financial analysts, technologists and constructors, production staff, personnel of the company, this improves the readiness and commitment to carry out all professional activities: marketing, finance, technologic, construction, manufacturing, personnel and others. Ideally, a stimulus program would be created that would be perfectly tailored to the needs and expectations of each employee. This, however, seems to be very demanding in economically, psychologically and timeconsuming conditions. In many cases, it seems to the managers that it is unnecessary to deal with minor differences in motivation profiles of employees. However, this is a serious managerial error and undermining the uniqueness and power of each individual, which can have a major impact on the neglect of job satisfaction and the resulting disruption of the overall performance of individuals and groups (Blašková, Hitka, 2011). The design and implementation of an effective and economically effective motivational program should be one of the key roles of each and every enterprise. An incorrectly and poorly applicable motivational program has a negative influence on the employees and simply does not motivate them to strive for maximum performance. At the current time, the motivation of the majority of employees in the majority of industrial manufacturing enterprises fails to meet all of the needs and requirements of those employees (Zámečník, 2014). 


\section{Material and methods}

Drawing on theoretical background and published facts, a structured questionnaire was created together with questions for an interview in order to obtain primary sources of information and qualitative data. Within the formulation of the questions in the structured questionnaire originally constructed by the authors we based our knowledge on the given vocational articles and publications.

The aim of the whole paper is to determine the development trends in motivation factors applied by business managers in a chosen international corporation which is the world's largest food and beverage company.

The paper is divided into two parts. In the first one we tried to analyse the difference in the use of motivation factors by business managers. One research hypothesis was formulated and tested: business managers differentiate the strength of motives of their subordinates.

In the second part of the paper we tried to determine the role and influence of the independent variables, namely leadership style, corporate culture and corporate communication on employee motivation in a chosen international corporation.

Primary data was obtained from a Likert questionnaire where respondents (managers at different levels of management in the international corporation) selected one of the five answers on a scale from 1 to 5 . The total number of managers within the corporation is 1000 . The sample was set done by Slovin formula and represents slightly more than 285 respondents.

Data processing was performed using MS EXCEL 2016 and SPSS. In the evaluation of the quantitative and qualitative statistical features the classification, relational and structural-genetic analysis was used. As a logical methodological principle of complementing the analysis, synthesis was used not only as the composition of individual phenomena or processes, but the creation of new entities. Mathematical and statistical methods and tests such as Friedman's Test, Wilcoxon Test were applied for statistical hypothesis testing.

Structural equation modelling was used to determine the correlation between dependent and independent variables. According to L. I. Syafii et al. (2015) we also implemented Partial Least Square Analysis in order to examine Linearity Test, Outer models Test, Inner models Test (structural test models). We also tested multicollinearity using Variance Inflation Factor (VIF) tests.

$$
\mathrm{VIF}=\frac{1}{1-R_{i}^{2}}
$$

\footnotetext{
$-1=$ not correlated.

- Between 1 and 5 = moderately correlated.

- Greater than 5 = highly correlated.
}

\section{Results}

All organizations must ensure that their employ ees achieve high performance at work. Therefore, they must pay attention to the most appropriate motivation means and use different tools such as remuneration, leadership, work and conditions in the organization. The company's goal is to create the right conditions for high employee's performance through motivation and work environment. The aim is not only to achieve organizational 


\begin{tabular}{|l|c|c|c|}
\hline & Strong & Weak & No motivation \\
\hline Financial Evaluation & 86 & 8 & 2.08 \\
\hline The Possibility of Self-Realization & 52 & 40 & 3.13 \\
\hline Social Respect & 52 & 32 & 10.42 \\
\hline The Opportunity to Participate in Decision-making & 40 & 47 & 6.25 \\
\hline Personal development & 49 & 42 & 4.17 \\
\hline Benefits & 71 & 21 & 3.13 \\
\hline
\end{tabular}

Fig. 2. Differentiating the effectiveness of motivation factors by managers

Source: the authors' own research.

goals but also to meet the personal needs of employees.

From the directive approach of management and motivation that has been common in the past, it is now completely retreating. Or they are only used in crisis situations. There is no universal way of managing and motivating (Šajbidorová, Lušnáková, 2013). Young and new companies apply a consultative or participative style. The easiest way is to listen to employees - about their goals and motivation. The manager regularly surveys the employee's opinion. He decides after considering the observations. In this way he also eliminates pressure on himself. $\mathrm{He}$ is trying to get approval from the team to make changes. There are open and constructive debates in teams where everyone can express themselves. Manager does not only listen to ideas, but also requires logical justification. He allows employees to work in the way they think most appropriate. However, the manager must consider the simplicity and functionality of the solution, the time-consuming, clear solutions, the investment requirements or the technical equipment of the company.

The motives are the driving force that leads man to activity. The truth is that the motivational profile of each individual is different. For each manager it is important to recognize and properly understand the needs and interests of their subordinates in order to identify their motives that activate them to meet the goals of the team in which they work, to participate actively in meeting the objectives of the enterprise. This knowledge is a prerequisite for effective communication and motivation. One of the partial goals of our research was to find out whether management distinguish the strength of the motives of its subordinates. The findings are shown in Figure 2.

Using the non-parametric Friedman's Test (Figure 3), the following two hypotheses were verified:

$\boldsymbol{H}_{0}$ : Managers do not differentiate the effectiveness of motivation factors of their subordinates

$\boldsymbol{H}_{\boldsymbol{I}}$ : Managers differentiate the effectiveness of motivation factors of their subordinates

\section{Friedman Test}

Test Statistics ${ }^{\text {a }}$

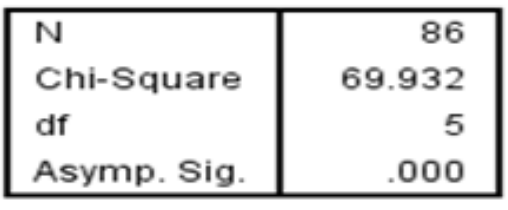

a. Friedman Test

Fig. 3. Friedman Test - differentiating the effectiveness of motivation factors by managers

Source: the authors' own research. 
Friedman's test shows us that p-value is 0.000 . Thus, if $\mathrm{p}<\alpha(0.000<0.05)$, we reject the $\mathrm{H} 0$ hypothesis of equality. Friedman's Test confirmed H1 hypothesis: Managers differentiate the effectiveness of motivation factors of their subordinates.

Subsequently, using Wilcoxon's posthoc test, we determine among which motives are the differences (Figures 4 and 5). We have formulated the following hypotheses:

HO: Management does not distinguish the strength of the two motivation factors of their subordinates.
H1: Management distinguishes the strength of the two motivation factors of their subordinates.

The Wilcoxon's Test results are processed in the form of a p-values table.

On the basis of p-values, management differentiates the power of the two motivational factors of its subordinates. From the managers' point of view, the most important motivation factor is the financial award. This is grouped into the first group of $\mathrm{p}$-values together with the benefits (non-financial benefits: commercial vehicles, mobile, computer, recreational

\begin{tabular}{|l|c|c|c|c|c|c|}
\hline & $\begin{array}{c}\text { Financial } \\
\text { Evalua- } \\
\text { tion }\end{array}$ & $\begin{array}{c}\text { The Possibil- } \\
\text { ity of Self- } \\
\text { Realization }\end{array}$ & $\begin{array}{c}\text { Social } \\
\text { Respect }\end{array}$ & $\begin{array}{c}\text { The Opportunity } \\
\text { to Participate in } \\
\text { Decision-making } \\
\text { Process }\end{array}$ & $\begin{array}{c}\text { Personal } \\
\text { Development }\end{array}$ & Benefits \\
\hline Financial Evaluation & 0.000 & 0.000 & 0.000 & 0.000 & 0.012 \\
\hline $\begin{array}{l}\text { The Possibility of } \\
\text { Self-Realization }\end{array}$ & & 0.194 & 0.020 & 0.433 & 0.006 \\
\hline Social Respect & & & & 0.250 & 0.564 & 0.000 \\
\hline $\begin{array}{l}\text { The Opportunity to } \\
\text { Participate in Decision- } \\
\text { making Process }\end{array}$ & & & & & 0.059 & 0.000 \\
\hline Personal Development & & & & & & \\
\hline Benefits & & & & & & \\
\hline
\end{tabular}

Fig. 4. Wilcoxon's Test results for combinations of motivation factors

Source: the authors' own research.

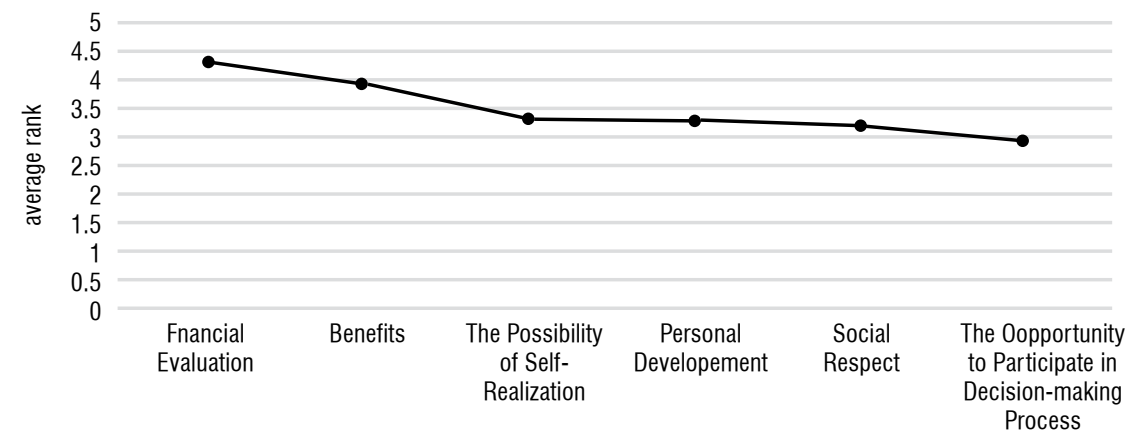

Fig. 5. Perceiving the importance of motivation by managers

Source: the authors' own research. 
and cultural events and others). The second group consists of the motives that are somewhat lower (from 3.40 to 3.00 ) on a five-step scale but are almost balanced.

On the other hand, it is primarily about the possibility of self-realization, then personal development, social recognition, and ultimately the possibility of participation in decision-making. In view of the results achieved, the rating is above average. Although motivation factors are included in the second group, they all have a significant impact on activating subordinates to achieve personal and corporate goals.

The analysed corporation belongs to innovative companies which increasingly committed to introducing creative forms of people's motivation. These companies see the main potential in a conscientious and systematic work with human capital. It is difficult to keep intelligent and loyal employees with their needs and visions. The effort is essential, and each manager must keep it in mind. Here are some options and examples of such incentives:

To promote motivation and creativity of employees by changing the working environment. Routine is the greatest enemy of creativity therefore companies provide more opportunities for employees to change the work place. An employee may be entitled to work from home. Chill out zone can be used by employees who do not like working in the office. Work from a park or café is supported if the home zone or chill out zone is not enough for creativity. Other opportunities to support employee motivation and creativity include regular out-of-office meetings or the possibility of staying in partner companies abroad.
Flexible working hours. According to the company's rules, there may be a fixed job, for example five hours. Each employee can decide how to work during the remaining hours.

Extra holidays to maintain mental well-being and ensure that workers do not suffer from resistance to work or even burnout syndromes.

Within Work-life Balance, an effort is made to properly balance employee's work responsibilities with activities in private life. Overtime cannot be an integral part of working time. The promotion of sport and the healthy lifestyle of all stakeholders who are encouraged to support each other also contributes to motivate employees to do good work.

Corporate culture, its build-up and follow-up and also frequent formal and informal teamwork outside the workplace contribute to employee loyalty and motivation to be part of society. Employees should enjoy their work. The only reliable way to achieve motivation is to encourage people to do things they love and care for.

An opportunity for further staff development is a number of educational events or events where employees, who are interested in, can lecture. They improve their public speech, learn and improve themselves. Employees can take the opportunity to move to another job, such as job rotation, to find out what job they like. Employees often have the opportunity to use the sophisticated internal education system that their organization offers them. In addition to attending various conferences, it also includes internal courses and trainings. Full-time employees are eligible for foreign language teaching. The advantage is if each employee has an individual 
development plan. Within the plan there are 2 to 3 areas where the employee would like to improve this year. An action plan (internal or external training, certificate, book) is prepared for each area.

Motivation through recognition and competitiveness. One of the things that naturally manages to motivate people is the expression of recognition, praise. This should be applied by the manager in everyday access to subordinates. Thanks to the overall effort to create an environment where people can praise, you will receive recognition for a good job not only from the boss but also from your colleagues.

The second aim of the paper was to determine the role and influence of the independent variables, namely leadership style, corporate culture and corporate communication on employee motivation.

Based on the results of the convergent validity testing, the value of a loading factor is more than 0.70 . The discriminant validity testing shown that the value of Average Variance Extracted (AVE) is qualified. Its values are more than the value of

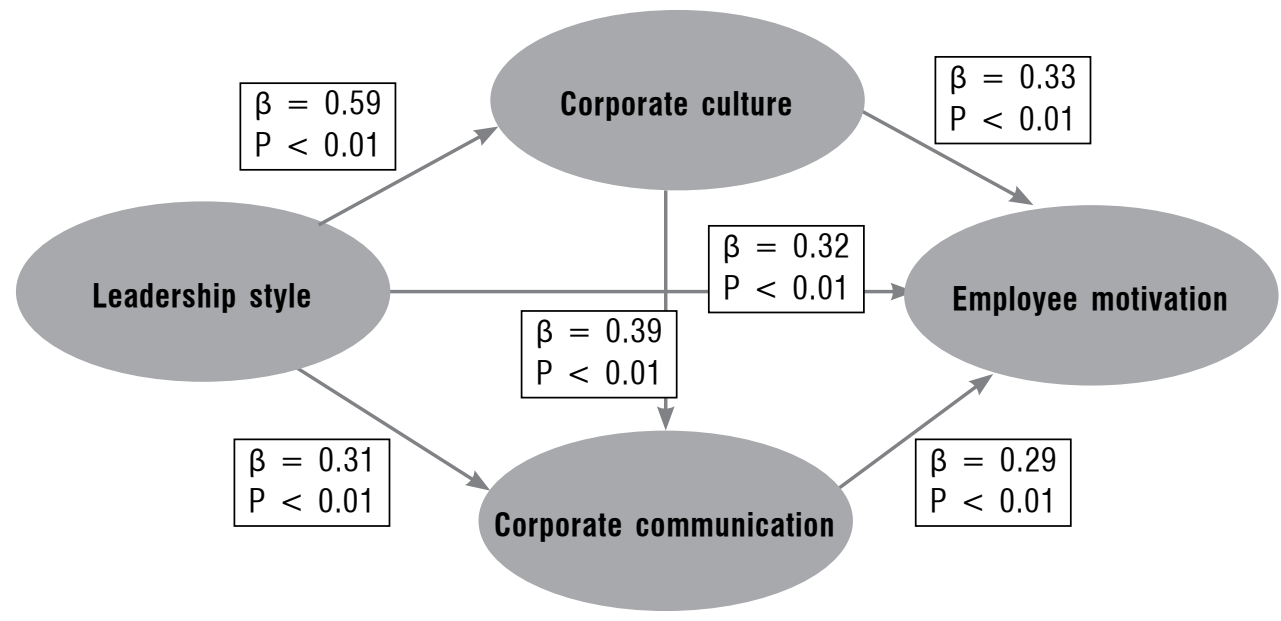

Fig. 6. Relationship between variables and PLS results

Source: the authors' own research.

Table 1. Direct influence between independent and dependent variable test results

\begin{tabular}{|c|c|c|c|l|}
\hline Independent Variable & Dependent Variable & Path Coeff & $P$ Value & Signif. \\
\hline Leadership Style & Employee Motivation & 0.32 & $P<0.01$ & Signif. \\
\hline Leadership Style & Corporate Culture & 0.59 & $P<0.01$ & Signif. \\
\hline Leadership Style & Corporate Communication & 0.31 & $P<0.01$ & Signif. \\
\hline Corporate Culture & Employee Motivation & 0.33 & $P<0.01$ & Signif. \\
\hline Corporate Culture & Corporate Communication & 0.39 & $P<0.01$ & Signif. \\
\hline Corporate communication & Employee Motivation & 0.29 & $P<0.01$ & Signif. \\
\hline
\end{tabular}

Source: the authors' own research. 
correlation variables. The value of Variance Inflation Factor (VIF) is below 3.1 which means there is no multicollinearity.

Reliability testing discovers faults and removes them before the software is put to use. Reliability testing describes that the composite reliability value is more than 0.80. Cronbach's alpha is a measure of internal consistency, that is, how closely related a set of items are as a group. Cronbach's alpha value is more than 0.8 .

Figure 6 shows the results and output of Partial Least Square Analysis. The results of the hypothesis testing are presented in Table 1.

Based on the results shown in the previous table we can state that corporate culture, corporate communication and also leadership style significantly affect the employee motivation. If the corporate culture variable is included as a mediation variable of leadership style on employee motivation, the effect remains significant. Similarly, if the corporate communication serves as a partial mediation of the influence of leadership style on employee motivation, the effect remains significant.

Corporate culture and corporate communication has a function as a partial mediation of the influence of leadership style on employees' motivation. If all the independent variables participate in a significant role, the motivation of employees' motivation will be very positive.

All motivation factors mentioned in the first part of our paper, as well as three independent variables from the second part, have to be actively involved in corporate motivation program which aim is to motivate employees in a systematic, coordinated and continuous way.

The proposal and implementation of an effective motivation program is one of the key management tasks of a company (Zámečník, 2014). Improperly designed and applied motivation programs can have a negative impact on employees, who are not motivated to achieve maximum performance.

The motivation program cannot be understood only as a listing of employee motivation factors. It has to be adapted to the corporate culture and possibilities of the enterprise. It must comply with the principles of motivational approach, not the full effect of motivational factors.

On the basis of the results, our recommendation for the corporation is to actively work on the establishment and refreshment of the motivation program of the company.

\section{Conclusions}

It is important for managers to recognize and properly understand the needs and interests of employees in order to identify their motives that activate them to meet the goals of the team in which they work and to participate actively in meeting the objectives of the company. This knowledge is a prerequisite for effective communication and motivation. One of the partial goals of our research was to find out whether management distinguish the strength of the motives of its subordinates. The result of Friedman's test is: "Managers differentiate the effectiveness of motivation factors of their subordinates." Using Wilcoxon's post-hoc test, we determine that management differentiates the power of the two motivational factors of its subordinates. From the managers' point of view the most important motivation factor is the financial award of work. 
Man has also described creative forms of people's motivation used in our corporation such as flexible working hours, staff development, work-life balance program, changing work environment and many others.

In the second part of the article, we determined the role and influence of the leadership style, corporate culture and corporate communication on employee motivation. Based on the results we can state that corporate culture, corporate communication and also leadership style significantly affect the employee motivation.
All motivation factors mentioned in the first part of our paper, as well as three independent variables from the second part, have to be actively involved in corporate motivation program which aim is to motivate employees in a systematic, coordinated and continuous way.

\section{Acknowledgements}

This paper was created within the KEGA project "Theory and practice of human resources management and managerial work". Project registration number 041SPU-4/2018.

\section{References}

1. Blašková, M., Hitka, M. (2011). Model riadenia pracovnej motivácie v priemyselných podnikoch. Vedecká monografia. Zvolen: DF TU.

2. Čihovská, V. et al. (2007). Manažment obchodného podniku. 1. vyd. - Bratislava: EKONÓM, 2007. 380 s.

3. Dermody, M. B., Young, M., Taylor, S. L. (2004). Identifying Job Motivation Factors of Restaurants Servers // International Journal of Hospitality \& Tourism Administration. Vol. 5, Issue 3.

4. Gilley, A., Gilley, J. W., McMillan, H. S. (2009). Organizational Change: Motivation, Communication, and Leadership Effectiveness / In Performance Improvement Quarterly. Vol. 21, Issue 4 pp. 75-94.

5. Chiang, Ch. F., Jang, S. Ch. (2008). An Expectancy Theory Model for Employee Motivation // International Journal of Hospitality Management. Vol. 27, Issue 2, pp. 313-322.

6. Kanfer, R., Chen, G. (2016). Motivation in Organizational Behavior: History, Advances and Prospects / In Organizational Behavior and $\mathrm{Hu}$ man Decision Processes. Vol. 136, pp. 6-19. doi: https://doi.org/10.1016/j.obhdp.2016.06.002.

7. Meyer, P. J. (2018). Citations of Famous Personalities. Internet access: https://citaty.net/ autori/pj-meyer/.

8. Mihalčová, B. et al. (2007). Riadenie ludských zdrojov. 1. vyd. - Bratislava: EKONÓM, 226 s.
9. Mikuláštík, M. (2015). Manažerská psychologie. 3. vyd. - Praha: Grada, 344 s.

10. Nohria, N., Groysberg, B., Lee, L. E. (2008). Employee Motivation. A Powerful New Model // Harvard Business Review. July - August 2008.

11. Plamínek, J. (2010). Tajemství motivace: jak zařídit, aby pro vás lidé rádi pracovali. 2. dopl. vyd. - Praha: Grada, 2010, 127 s.

12. Rajhans, K. (2012). Effective Organizational Communication: A Key to Employee Motivation and Performance // Interscience Management Review (IMR). Vol. 2, Issue 2.

13. Ramlall, S. (2004). A Review of Employee Motivation Theories and their Implications for Employee Retention within Organizations // The Journal of American Academy of Business. Cambridge. Vol. 9, pp. 52-63.

14. Raudeliūnienè, J., Meidutè-Kavaliauskienè, I (2014). Analysis of Factors Motivating Human Resources in Public Sector // Procedia - Social and Behavioral Sciences. Vol. 110, January, pp. 719-726. doi: https://doi.org/10.1016/j. sbspro.2013.12.916.

15. Syafii, L. I., Thoyib, A., Nimran, U., Djumahir (2015). The Role of Corporate Culture and Employee Motivation as a Mediating Variable of Leadership Style Related with the Employee Performance (studies in Perum Perhutani) // Procedia - Social and Behavioral 
Sciences. Vol. 211, pp. 1142-1147. doi: 10.1016/j. sbspro.2015.11.152.

16. Šajbidorová, M. (2008). Leading Style as an Employees Motivation Equipment / In International Scientific Days 2008: Competitiveness and Economic Growth. European and national perspectives: proceedings of reviewed articles of International scientific conference, May 28-30, 2008 Nitra, the Slovak Republic. - Nitra: Slovenská polnohospodárska univerzita. Pp. 603-606.

17. Šajbidorová, M., Lušňáková, Z. (2013). The Impact of Leadership Styles on Employees motivation / In Business Management - Practice and Theory in the 21st century: international scientific conference: proceedings of scientific papers, June 6-7, 2013, Nitra: Slovak University of
Agriculture. pp. 604-607. Internet access: http:// www.slpk.sk/eldo/2013/zborniky/03-13/se3/Sajbidorova_Lusnakova.pdf

18. Vetráková, M., Mazúchová. L. (2015). Modeling of Process Work Motivation in Hotels // Procedia Economics and Finance. Vol. 34, pp. 508-513. doi: https://doi.org/10.1016/ S2212-5671(15)01661-5.

19. Zámečník, R. (2014). The Measurement of Employee Motivation by Using Multi-factor Statistical Analysis // Procedia - Social and Behavioral Sciences. Vol. 109, January, pp. 851-857. doi: https://doi.org/10.1016/j.sbspro.2013.12.553.

The paper submitted: May 7, 2018

Prepared for publication: June 29, 2018

Zuzana LUŠŇÁKOVÁ, Mária ŠAJBIDOROVÁ, Zuzana JURÍČKOVÁ MOTYVACIJOS VEIKSNIAI ORGANIZACIJOJE BEI JŲ VYSTYMO GALIMYBĖS

\author{
S a n tra u k a
}

Aukšta darbuotojų motyvacija ir gerai sukurta vidinè komunikacija darbdaviui suteikia svarbų konkurencinị pranašumą prieš kitas ịmones.

Straipsnio tikslas - apibrežti motyvacinių veiksnių vystymo kryptis, taikomas verslo vadovų pasirinktose tarptautinèse i̇monèse.

Straipsnis padalytas ị dvi dalis. Pirmoje dalyje analizuojami verslo vadovų naudojami motyvacijos būdų skirtumai. Viena tyrimo hipotezè buvo suformuluota ir patikrinta: verslo vadovai diferencijuoja savo pavaldinių motyvacijos stiprumą.

Antroje dalyje buvo siekiama nustatyti vaidmenų ir nepriklausomų kintamųjų, tokių kaip, lyderystès stilius, organizacinè kultūra ir organizacijos komunikacija ịtaką darbuotojų motyvacijai pasirinktose tarptautinèse įmonèse.

Pirminiai duomenys gauti iš Likerto skalès klausimyno, kur respondentai (skirtingų lygiụ tarptautinių i̇monių vadovai) pasirinkdavo vieną iš penkių galimų atsakymų, skaleje nuo 1 iki 5 . Bendras skaičius vadovų i̇monèse yra 1000. Remiantis Slovin formule, nustatyta imtis - kiek daugiau nei 285 respondentai.

Duomenų apdorojimas atliktas naudojant MS EXCEL 2016 ir SPSS programas. Statistiniam hipotezès testavimui naudoti matematiniai ir statistiniai metodai ir testai, tokie kaip, Friedmano testas ir Wilcoxono kriterijus. Struktūrinis lyginimo mode- liavimas buvo naudojamas siekiant nustatyti koreliaciją tarp priklausomų ir nepriklausomų kintamųjų. Remiantis L. I. Syafii et al. (2015), taip pat buvo atlikta mažiausių dalinių kvadratų (PLS) analizè, siekiant išanalizuoti linijiniškumo testą, išorinių ir vidinių modelių testus. Taip pat patikrintas multikolinearumas naudojant dispersijos mažèjimo daugiklị (variantiškumo veiksnị) (VIF).

Vienas iš dalinių tyrimo tikslų buvo išsiaiškinti, ar vadovai išskiria savo pavaldinių motyvų stiprumą. P-vertybių pagrindu, naudojant Wilcoxono kriterijų, vadovai išskiria dviejų motyvacinių veiksnių stiprumą. Vadovų požiūriu pagrindinis ir svarbiausias motyvacinis veiksnys - finansinis apdovanojimas. Tai sugrupuota pirmoje p-vertybiu grupejje kartu su teikiamomis naudomis (nefinansinès naudos: komercinis transportas, mobilusis, kompiuteris, poilsiniai ir kultūriniai renginiai ir kt.). Antra grupe sudaryta iš motyvų, kurie yra šiek tiek žemiau (nuo 3,40 iki 3,00) penkiu balu skalejje, bet yra beveik proporcingi. Remiantis rezultatais, pirmiausia svarbi galimybè save realizuoti, tada asmeninis tobulejjimas, socialinis pripažinimas ir galimybè dalyvauti sprendimų prièmime. Atsižvelgiant i gautus rezultatus, reitingas yra šiek tiek didesnis nei vidurkis. Nors motyvaciniai veiksniai įtraukti i antrą grupę, tačiau jie turi reikšmingą įtaką igalinant pavaldinius siekti asmeninių ir ịmonés tikslų. 
Antras tyrimo tikslas - nustatyti vaidmenų ir nepriklausomų kintamụjų, tokių kaip, lyderystès stilius, organizacinè kultūra ir organizacijos komunikacijos įtaką darbuotojų motyvacijai.

Remiantis konvergentiškumo patikimumo testo rezultatais, apkrovos faktoriaus verte daugiau nei 0,70. Diskriminantinio patikimumo testas parode, kad vidutinès dispersijos verte (AVE) yra tinkama. Jos vertès yra didesnès nei koreliacijų kintamųjų vertès. Dispersijos mažejjimo daugiklio vertè (VIF) yra žemiau 3,1, o tai reiškia, jog multikolinearumo nèra.

Patikimumo ivvertinimas rodo, kad sudètinè patikimumo vertè yra daugiau nei 0,80 . Cronbach alpha yra vidaus pastovumo matas, tai yra kaip artimai susijusių dalykų rinkinys yra kaip grupè. Cronbach alpha daugiau kaip 0,8.

Remiantis gautais rezultatais, galima teigti, kad organizaciné kultūra, organizacijos komunikacija ir lyderystės tipas reikšmingai veikia darbuotojų motyvaciją. Jei organizacinès kultūros kintamasis yra mediacinis lyderystès tipo darbuotojų motyvacijos kintamasis, rezultatas išlieka reikšmingas. Jeigu įmonés komunikacijos kintamasis atstoja dalini mediacini lyderystės stiliaus darbuotojų motyvacijai ịtakos kintamąji, o rezultatai išlieka reikšmingi.

Vadovams svarbu atpažinti ir tinkamai ịvardyti darbuotojų poreikius ir interesus, siekiant identifikuoti jų motyvus, kurie skatina juos veikti ir siekti tiek komandos, kurioje jie dirba, tiek visos įmonès tikslų. Šios žinios yra būtina sąlyga efektyviai komunikacijai ir motyvacijai. Visi pirmoje straipsnio dalyje pamineti motyvacijos veiksniai, taip pat ir trys nepriklausomi kintamieji aprašyti antroje straipsnio dalyje turi būti ịtraukti i įmonès motyvacijos programą, kurios tikslas yra sistemiškai, koordinuotai ir nuolat motyvuoti darbuotojus. 